\title{
E-dictionary Use under the Spotlight: Students' Use of Pocket Electronic Dictionaries for Writing
}

Atipat Boonmoh, Department of Language Studies, School of Liberal Arts, King Mongkut's University of Technology Thonburi, Bangmod, Thailand (atipat.boo@kmutt.ac.th/atipat_b@yahoo.com)

\begin{abstract}
This article reports on the utilisation of pocket electronic dictionaries (PEDs) for writing by learners of English at a Thai university. It aims to enrich the study of dictionary use behaviour by investigating, through the use of combined research methods, exactly what happens when students use PEDs for production. The participants in this study included 13 students who were chosen from a group of 1211 students enrolled in a foundation English course at a university in Thailand. Data were collected using a think-aloud protocol, observation, and retrospective interviews as data collection methods. The first eight participants were asked to read a passage in Thai. Using dictionaries in their PEDs, they were asked to write a summary in English (the Water I experiment). The remaining five participants followed the same procedure, but after the summary task was completed, they were asked to review their summaries using the Oxford Advanced Learner's Dictionary, and the English-English dictionary in their PEDs (the Water II experiment). The experimental study revealed how the participants tackled the reading passage and wrote summaries, the problems they encountered, and the strategies they used to solve these problems. A graphic representation of the PED consultation process was also proposed. The use of the EnglishEnglish dictionary in their PEDs helped some participants review their English summaries. It was found that some participants failed to display (extended) knowledge of the PEDs they were using. The investigations revealed several factors that may have hampered dictionary lookup success as well as factors that may have promoted dictionary lookup success.
\end{abstract}

Keywords: DICTIONARY USE, POCKET ELECTRONIC DICTIONARY, DICTIONARY CONSULTATION, MONOLINGUAL DICTIONARY, BILINGUAL DICTIONARY, WRITING

Opsomming: E-woordeboekgebruik onder die soeklig: Studente se gebruik van elektroniese sakwoordeboeke vir skryfwerk. In hierdie artikel word verslag gedoen van die gebruik van elektroniese sakwoordeboeke (ESW'e) vir skryfwerk deur aanleerders van Engels by ' $n$ Thaise universiteit. Daar word gepoog om die studie van woordeboekgebruiksgedrag te verryk deur ondersoek in te stel na presies wat gebeur wanneer studente ESW'e gebruik vir skryfwerk deur gebruik te maak van gekombineerde navorsingsmetodes. Die deelnemers aan hierdie studie het 13 studente ingesluit wat gekies is uit 'n groep van 1211 studente wat aan ' $n$ universiteit in Thailand ingeskryf was vir 'n kursus in basiese Engels. Data is versamel deur middel van 'n hardopdinkprotokol, waarneming en retrospektiewe onderhoude as dataversamelingsmetodes. Die eerste agt deelnemers is gevra om ' $n$ gedeelte in Thai te lees. Hulle is gevra om 'n opsomming in Engels te skryf (die Water I-eksperiment) terwyl hulle woordeboeke in hulle ESW'e 
gebruik. Die oorblywende vyf deelnemers het dieselfde prosedure gevolg, maar nadat die opsommingstaak afgehandel is, is hulle gevra om hulle opsommings te kontroleer deur die Oxford Advanced Learner's Dictionary en die Engels-Engels-woordeboek in hulle ESW'e te gebruik (die Water II-eksperiment). Die eksperimentele studie het getoon hoe die deelnemers die leesgedeelte aangepak en opsommings geskryf het, watter probleme hulle teëgekom het en watter strategieë hulle gebruik het om hulle probleme op te los. 'n Grafiese voorstelling van die proses van hoe die ESW'e geraadpleeg is, is ook aangebied. Die gebruik van die Engels-Engels-woordeboek in hulle ESW'e het sommige deelnemers gehelp met die kontrolering van hul Engelse opsommings. Daar is bevind dat sommige deelnemers nie 'n (uitgebreide) kennis kon toon van die ESW'e wat hulle gebruik het nie. Die ondersoeke het verskeie faktore blootgelê wat die sukses van naslaan in die woordeboek sou kon belemmer, sowel as faktore wat die sukses van naslaan sou kon bevorder.

Sleutelwoorde: WOORDEBOEKGEBRUIK, ELEKTRONIESE SAKWOORDEBOEK, WOORDEBOEKRAADPLEGING, EENTALIGE WOORDEBOEK, TWEETALIGE WOORDEBOEK, SKRYFWERK

\section{Introduction}

Research (e.g. Deng 2005, Midlane 2005, Taylor and Chan 1994) indicates a growing number of pocket electronic dictionary (PED) users in many South and East Asian countries due to the advance of technology, PED ease of use and their portable size. Pocket electronic dictionaries (PEDs) are common in Thailand (Boonmoh and Nesi 2008, Mongphet 2007), and are often advertised in terms of their technological features - what PEDs can do and what hardcopy dictionaries are contained in them - rather than lexicographical features. PEDs are available for sale in major department stores, and PED booths from different manufacturers are normally located next to each other. Their prices are more affordable than in the past. For these reasons, the PED phenomenon can be observed throughout Thailand.

This study has its origin in observations of this phenomenon when the author was employed as a language lecturer at a university in Thailand. It was observed that many students brought PEDs into the classroom and often consulted their PEDs when writing. Although dictionary skills training lessons had been included in foundation English courses at the university and students were encouraged to use any English learners' dictionaries, the students seemed to prefer using PEDs when left to their own devices. Lecturers, however, often complained about the students' language mistakes. Many of them commented that these mistakes could have been made as a result of the PEDs students were using. These teachers seemed to take a negative view when students used PEDs. A discussion with a few colleagues revealed that they did not use PEDs, did not know much about what PEDs can offer, and probably had less knowledge about PEDs than the students.

Information about Thai PEDs is limited and is not often available to Thai lecturers. The PED manufacturers do not promote their products from a lexicographical perspective. Moreover, most of the existing PED studies do not refer to 
the Thai context. Therefore, it may not be justified for the teachers to question the quality of PEDs students use without having access to empirical data concerning how students actually use their PEDs. This study aims to find out which processes take place and which procedures are followed when students use PEDs in text production.

\section{Literature review}

\subsection{Research into pocket electronic dictionary use}

PEDs have been available for the last thirty years but research into PED use is in its infancy (Jopling 2003, Tono 2001). Most previous studies refer to electronic dictionaries on CD-ROM that were produced by famous publishing houses and can be easily reviewed from a lexicographical perspective. On the other hand, most of the few PED studies (e.g. Taylor and Chan 1994, Deng 2005, Stirling 2005) have been confined to quantitative ownership surveys, and qualitative investigations into teacher and student attitudes and beliefs. A few simple experiments have been conducted, such as a lookup 'race' between PED and print dictionary users (Weschler and Pitts 2000). There have been few studies on how people actually use pocket electronic dictionaries. The few studies that looked closely at what happens when electronic dictionaries are consulted were mainly concerned with the use of learner's dictionaries on CD-ROM (Jopling 2003, Nesi and Haill 2002, Winkler 2001), and an online bilingual dictionary (Liou 2000).

PEDs are popular with students especially in South and East Asian countries. In Taylor and Chan's (1994) survey of 475 Hong Kong students, $18 \%$ used PEDs, and $70 \%$ of 80 Chinese college students in Deng's (2005) survey were PED users. Most of the 11 EFL students in a UK language school interviewed by Stirling (2005) were in favour of PEDs. Teachers in Midlane's (2005) survey reported students bringing PEDs in the classroom. A recent questionnaire survey conducted by Boonmoh and Nesi (2008) showed that although almost all Thai students (938 out of 1211) reported owning learner's dictionaries in book form, only 102 and 46 respectively stated that they normally used these dictionaries for reading and writing. On the other hand, the number of students who reported owning PEDs (456 students) was found to correspond well with the number of students who reported using them (435 for reading, and 412 for writing). Interestingly, the number of students who reported they wanted to buy PEDs in the future rose to 818 as opposed to 117 students who reported they wanted to buy learner's dictionaries in book form. PEDs are a promising tool for students. Students increasingly prefer PEDs to dictionaries in book form. As Midlane (2005: 125) points out, one aspect of the growth in PED use is because "it had been a bottom-up movement". It is student-led - not led by teachers or lexicographers. Furthermore, the greater use of PEDs may to a certain extent change the nature of classroom learning. 
Teachers' views of PEDs, on the other hand, tend to be quite negative. Teachers complain that PED contents are inadequate. Deng (2005) claims that the PEDs his students use in China do not supply English definitions, inflectional forms or examples. Koren (1997) reports that Israeli teachers object to PEDs because they lack "word meanings, word families, parts of speech, tense, usage and idioms, etc." Several of the 11 EFL teachers in the UK interviewed by Stirling (2005) also complained about "inaccurate meanings" and "insufficient examples". Boonmoh and Nesi's (2008) survey of 30 lecturers of English reveals that lecturers are highly critical of the PED as a tool for students, and many refer to the inadequacy of the dictionary information it provides.

It is seen, on the one hand, that the students are overwhelmingly in favour of PEDs. The teachers, on the other hand, have negative attitudes towards PED use as they believe PEDs to be noisy and distracting. They are also more critical of the students' use of PEDs. Knowing only 'which' dictionaries students use, however, may not be sufficient. In order to help teachers to be able to provide authoritative advice on PED purchases, and develop e-dictionary skill training programmes, it is important to find out "exactly what ... students are doing with their dictionaries, what they expect from them, and how easily they are satisfied during the process of consultation" (Atkins and Varantola 1998: 115). A number of studies that attempt to uncover how students actually use dictionaries for reading can be found in Liou (2000), Winkler (2001), Wingate (2004) and Nesi and Boonmoh (2009). Liou focuses on online bilingual dictionaries, Winkler on learner's dictionaries on CD-ROM, and Wingate on dictionaries in book form. An attempt to uncover how students use PEDs can be found in Nesi and Boonmoh (2009). In their study, Nesi and Boonmoh investigate how Thai students use their PEDs for reading. The findings suggest that the subjects failed to display dictionary skills and knowledge of the PEDs they were using.

In order to complete the picture of PED use for both receptive and productive purposes, this study aims to report on how PEDs are utilised for writing. The purpose of this study is, therefore, to answer the following two questions:

- How do Thai students use their pocket electronic dictionaries to read a passage in Thai in order to write a summary in English?

- How successful are their PED consultations?

\subsection{Methodological options for PED research}

Questionnaire research is perhaps the most common method of enquiry into the use of dictionaries. Many studies have been confined to surveys, mainly conducted by means of questionnaires (Deng 2005, Midlane 2005, Sobkowiak 2002, Tang 1997, and Taylor and Chan 1994), since they can be used as a way of obtaining results from a great number of respondents. They can be useful for identifying general trends which might then be examined more closely in smaller, more empirical studies. A questionnaire alone, however, cannot reveal "exactly 
what ... students are doing with their dictionaries, what they expect from them, and how easily they are satisfied during the process of consultation" (Atkins and Varantola 1998: 115). For this reason, it seems a good idea to triangulate questionnaire data with more qualitative data obtained by other means.

Interviews can be used to elicit opinions, and interactive settings are another step towards gathering more direct evidence of dictionary lookup behaviour. The interview questions can be structured, but can also be flexible in the sense that interviewers may ask further questions related to the interviewees' reply. Although an interview cannot reveal exactly how students actually use PEDs, it may be a useful device to use retrospectively and to obtain data which can be triangulated with those collected in the same study through the use of other techniques. Previous research which employs interviews together with other research instruments includes Diab (1990), Winkler (2001) and Boonmoh (2003).

Observation is an obvious means of collecting data in educational settings, but PED displays are much smaller than computer screens or the printed page, so it is very difficult for teachers or researchers to see what is happening during a student's PED consultation. PED consultation is also a private activity, and one which learners are often inclined to be secretive about (Nesi and Boonmoh 2009, Nesi and Haill 2002). Observing PED use in a natural setting is, therefore, almost impossible. Video recording users, a method employed by Jopling (2003) when investigating the use of CD-ROM dictionaries, is not a practical means of researching PED use. Although 'spy' software - a method used in Liou (2000) has some potential as a means of observing online dictionary use (through keystroke logging and screenshots), it cannot be loaded into the standard PED.

Another method of investigating dictionary use involves lookup record sheets. Some studies that have employed this method are Atkins and Varantola (1998), Diab and Hamdan (1999), Al-Ajmi (2002), Paisart (2004) and Frankenberg-Garcia (2005). Asking students to record words they look up, however, may not be appropriate for research into how PEDs are really used. This is because the focus of the study would be on the final decision of the students rather than the entire lookup process. Since PED use is much quicker than paper-based dictionary use (Weschler and Pitts 2000) and the speed encourages more lookups, supplying information for the dictionary record sheets would disrupt lookup and reduce the speed of consultation, and as a consequence discourage subjects from looking up words.

Another possible methodology is self-observation, as opposed to observation by the researcher. This can be in the form of retrospection or introspection. Retrospection requires subjects to report their working process after finishing the task; however, the limitations of memory can affect the quality of data reported in this way, especially given the unsatisfactory nature of video recordings of PED use.

Think-aloud data are basically unedited and unanalysed, as subjects are not in any way controlled or directed. There are, however, drawbacks and "this procedure is not a replacement for other research methodologies for investigating mental processes" (Cohen 1998: 39). For example, the process seems to 
work better with extrovert subjects (introverts often fail to provide sufficient data), and there is a danger that subjects may modify what they say in order to meet the perceived needs of the researcher. Moreover, if the task is too easy, subjects may not be able to access their own thought processes, because the process of comprehending will be too quick and automatic (Ericsson and Simon 1980: 225, cited in Matsumoto, 1993: 48-49). Researchers must therefore pay particular attention to the selection of texts and tasks, but provided that this is done, think-aloud seems to be one of the most appropriate instruments for PED research.

Dictionary consultation is a private matter and there is no way of discovering what people actually do when they use a dictionary without, to a certain degree, interfering with their natural behaviour. Using a log file can help reveal this, but it is limited to observing dictionary use on CD-ROM or on the Internet. Observation can look at how students use dictionaries in a natural setting but only observable behaviours can be observed. To reveal their mental working processes, the subjects need to verbalise. Asking the subjects to verbalise will inevitably disrupt the subjects' working processes. This study, therefore, will employ a mix of research instruments in order to uncover exactly how participants use their PEDs for writing.

\subsection{Pocket Electronic dictionaries in Thailand}

Before exploring how PEDs are used, it is necessary to give some idea of the range of features Thai PEDs offer. A Thai PED normally contains at least three paper-based dictionaries: two bilingual English-Thai and Thai-English, and one English monolingual. There are at least four companies that produce PEDs in Thailand, but TalkingDict (Group Sense Ltd.) and CyberDict (Besta) are the leading brands. Over the past two decades, TalkingDict has published more than 20 models and CyberDict, which was established a few years later, has published more than 16 models. An investigation of two PED models by Boonmoh (2009), the Super Smart by TalkingDict and the CyberDict 3 Advance by CyberDict, found the main difference to be lexicographical features.

It is seen from Table 1 that CyberDict 3 Advance contains material from newer and more up-to-date paper-based dictionaries than Super Smart. More recent PED models by TalkingDict replaced the paper-based English-English Concise American Heritage Dictionary with the Concise Oxford English Dictionary (11th edition, 2006). It should be noted that the Concise Oxford English Dictionary is not intended for learners of English but for native speakers of English. Some newer TalkingDict models claim to contain the Oxford River Books English-Thai Dictionary and the Cambridge Advanced Learner's Dictionary (unstated edition). The contents of the English-Thai and Thai-English dictionaries of these two PED brands, however, remain the same. 
Table 1: Comparison of two PED models

\begin{tabular}{|l|l|l|}
\hline Dictionary & \multicolumn{1}{|c|}{ Super Smart } & \multicolumn{1}{c|}{ CyberDict 3 Advance } \\
\hline $\begin{array}{l}\text { Thai- } \\
\text { English }\end{array}$ & $\begin{array}{l}\text { Compiled by lecturers from the } \\
\text { Chalermprakiat Center of Transla- } \\
\text { tion and Interpretation (undated) }\end{array}$ & $\begin{array}{l}\text { Thiengburanathum, W. 2002. Thai-English } \\
\text { Dictionary. Library Edition. Bangkok: } \\
\text { รวมสาส์น. }\end{array}$ \\
\hline $\begin{array}{l}\text { English- } \\
\text { Thai }\end{array}$ & $\begin{array}{l}\text { Compiled by lecturers from the } \\
\text { Chalermprakiat Center of Trans- } \\
\text { lation and Interpretation } \\
\text { (undated) }\end{array}$ & $\begin{array}{l}\text { Thiengburanathum, W. 1998. SE-ED's } \\
\text { Modern English-Thai Dictionary (Complete and } \\
\text { Updated) Desk Reference Edition, Bangkok: SE- } \\
\text { Education. }\end{array}$ \\
\hline $\begin{array}{l}\text { English- } \\
\text { Thai }\end{array}$ & - & $\begin{array}{l}\text { Mallikamas, P., N. Chakrabongse and P. } \\
\text { Piammaattawat. 2004. Oxford River Books } \\
\text { English-Thai Dictionary. Bangkok: River } \\
\text { Books. }\end{array}$ \\
\hline $\begin{array}{l}\text { English- } \\
\text { English }\end{array}$ & $\begin{array}{l}\text { The Concise American Heritage } \\
\text { Dictionary. (1983, Houghton } \\
\text { Mifflin) }\end{array}$ & $\begin{array}{l}\text { Hornby, A.S. 2000. Oxford Advanced Learner's } \\
\text { Dictionary. 6th Edition. Oxford: Oxford Uni- } \\
\text { versity Press. }\end{array}$ \\
\hline
\end{tabular}

\section{Methodology}

\subsection{Subjects}

The participants in this study included 13 students chosen from a cohort of 1211 students (reported in Boonmoh and Nesi, 2008) enrolled in a foundation English course (Fundamental English II) in the 2007 academic year at a university in Thailand. They were from three faculties: Faculty of Engineering, Faculty of Sciences and Faculty of Industrial Engineering. These 13 subjects were selected because, in an earlier questionnaire survey, they had claimed to possess and use pocket electronic dictionaries, and had indicated their willingness to participate in the experiment. All the participants had passed a foundation English course (Fundamental English I) which included dictionary skills training lessons.

The first eight participants were asked to read a passage in Thai. Using dictionaries in their PEDs, they were asked to write a summary in English (the Water I experiment). They used TalkingDict or CyberDict PEDs with a variable combination of bilingual and monolingual English dictionaries (the Concise American Heritage Dictionary for TalkingDict PEDs, and the Oxford Advanced Learner's Dictionary for CyberDict PEDs).

The remaining five participants, who used CyberDict models, followed the same procedures, but additionally after the summary task was completed they were asked to review their summaries using the Oxford Advanced Learner's Dictionary, the monolingual English dictionary in their PEDs (the Water II experiment). The aim of the Water II experiment was to see what difference it would make when the participants used the $O A L D$ 6th edition to write a summary in English. 


\subsection{Instruments}

A think-aloud protocol, observation, record sheet keeping and interviews were employed as data collection instruments in this study. The questionnaires were not only used as part of the surveys (reported in Boonmoh and Nesi 2008) but were also used to select potential participants for the Water experiments. The author's presence during the experiments enabled him to observe the whole 'visible' process of PED consultation. The think-aloud procedure allowed him to explore the participants' mental working processes which are 'invisible' when they are doing the tasks. Finally, the interview enabled the author to ask related questions concerning the participants' previous use of PEDs as well as providing the participants with the opportunity to clarify their working processes and their feelings after completing the tasks. Combining the data from these instruments would make the findings richer and more reliable.

\subsection{Procedure}

The 13 participants who were initially selected based on the findings of the questionnaire (see the Subject section above), underwent think-aloud training. The training consisted of two periods, i.e. the first was in plenary, and the second was individual (on the day each participant came to do the summary tasks). Participants were asked to read a Thai reading passage "Water" taken from Wikipedia, the free encyclopedia in the Thai version (See Appendix A for the reading passage). Then, they were asked to write a summary in English. This text had been piloted with a comparable group of volunteers, and had proven to be appropriate in terms of topic, difficulty level and length.

The participants were asked to complete the task in individual sessions. The author also observed every word looked up and completed an observation check sheet. The check sheets were used to record the words and meanings the participants looked up and to ask specific questions during the retrospective interviews conducted with each subject at the end of the session. (See Appendix B for interview schedule.)

\subsection{Data analysis}

Findings were derived from consideration of four data sources: think-aloud protocols, participants' written summaries in English, observation notes and interviews. The data were analysed only in cases where the participants consulted their PEDs to write English summaries. The number of words looked up and the number of successful and unsuccessful lookups were noted. The data from the interviews and the observation check sheets were analysed with reference to the following questions:

1. How did the participants write their summaries?

2. Which words did the participants look up in the PEDs? 
3. Did they find the words they looked up? If not, why were they unable to find them?

4. Did they select any words found in the PEDs to use in the summary? If yes, which word did they select and why? If no, why not?

5. What did they do if they did not find the words they looked up or if they did not select any words after the lookup?

6. If they did not choose any word, what did they do?

\section{Findings}

\subsection{The Water I Experiment}

Table 2 summarises the participants' approaches to the task of summary writing.

Table 2: Participants' approaches to the summary task

\begin{tabular}{|l|l|l|l|l|l|l|l|l|}
\hline \multicolumn{2}{|c|}{ Procedures } & \multicolumn{7}{c|}{ Participants } \\
\hline & A & B & C & D & E & F & G & H \\
\hline $\begin{array}{l}\text { Participants read the passage word by word } \\
\text { and looked up equivalents of the L1 words. }\end{array}$ & $\checkmark$ & & & & & & & \\
\hline Participants read the whole passage first. & & $\checkmark$ & $\checkmark$ & $\checkmark$ & $\checkmark$ & $\checkmark$ & $\checkmark$ & $\checkmark$ \\
\hline $\begin{array}{l}\text { Participants wrote a summary in Thai and } \\
\text { then translated it into English. }\end{array}$ & & & & & & & & \\
\hline $\begin{array}{l}\text { Participants searched for English equivalents } \\
\text { while writing a summary. }\end{array}$ & & & & & & & & $\checkmark$ \\
\hline $\begin{array}{l}\text { Participants underlined the key words before } \\
\text { starting to look them up. }\end{array}$ & & $\checkmark$ & & & & & & \\
\hline $\begin{array}{l}\text { Participants reviewed the summary before } \\
\text { submitting it to the researcher. }\end{array}$ & & & & & & & & $\checkmark$ \\
\hline
\end{tabular}

Figure 1 is a graphic representation of the different lookup stages during the PED consultation. It represents how the participants started a search, what problem(s) they had, and how they tried to solve the problem(s). The first step is concerned with whether or not the participants consulted their PEDs when writing the summary. If the participants did not consult their PEDs, those words or sentences were ignored, regardless of whether the participants used the words correctly or incorrectly. In contrast, if the participants consulted their PEDs, the analysis was continued in order to discover the reason(s) for this. 
The second step is to ascertain whether the participants found the target word in the dictionary or not. If they found the target word in the dictionary (Yes), a third step was then analysed. The PED consultation was considered successful if the participants found the word they were looking for. If the participants were not able to find the target word through PED consultation, there were three possible reasons for this:

- The participant typed in the incorrect spelling of either the Thai or English word.

- The target word the participant was looking for was not in the PED.

- The search term was a multi-word unit. In some cases such a multi-word unit could have been broken down into separate components (which still conveyed the same sense).

The third step concerns the ability to locate an English word or phrase in the entry which is an appropriate equivalent for the Thai search term. Being able to locate appropriate equivalents is considered to be a success at a deeper level. However, deciding whether the participants located appropriate equivalents is not a straightforward business. The participants often did not simply locate the English equivalent and use it in their summary. They usually employed other, more complex strategies. It can be seen that not every lookup can be classified as either appropriate (yes) or inappropriate (no) since for some lookups the participants did not immediately choose which equivalent(s) they would use in the summary. Instead, they chose one of three alternative routes:

- They might look up the same word again.

- $\quad$ They might look up the translation(s) of the English equivalents (related word type II). For example, a search for the Thai word บึง [bueng] yielded "n. a bog, a fen, a marsh, a swamp". B wanted to choose one of the equivalents but was not sure which one was the most appropriate. He therefore searched for the translations of the words BOG, FEN, and MARSH in the default English-Thai dictionary before making a decision.

- They might search for other Thai words that have similar meanings or share the same root (related word type I). For example, B wanted to find the equivalent of the word ปรากฏการณ์ [prakotkan] (phenomenon) but made a mistake when typing in this word, so it yielded no results. He then searched for other Thai words ปรากฏ [prakot] (to appear, to be evident, to be known, to take place), and used the word wheel facility to scroll down and successfully find the word ปรากฏการณ์ [prakotkan] (phenomenon).

The related search type I is different from the related search type II in the sense that the former involves the headword in Thai while the latter involves the headword in English. 
Having employed these complex strategies, participants then made a decision regarding which translation equivalent of the search term they should use. If the participant was able to locate an appropriate equivalent, a fourth stage was analysed.

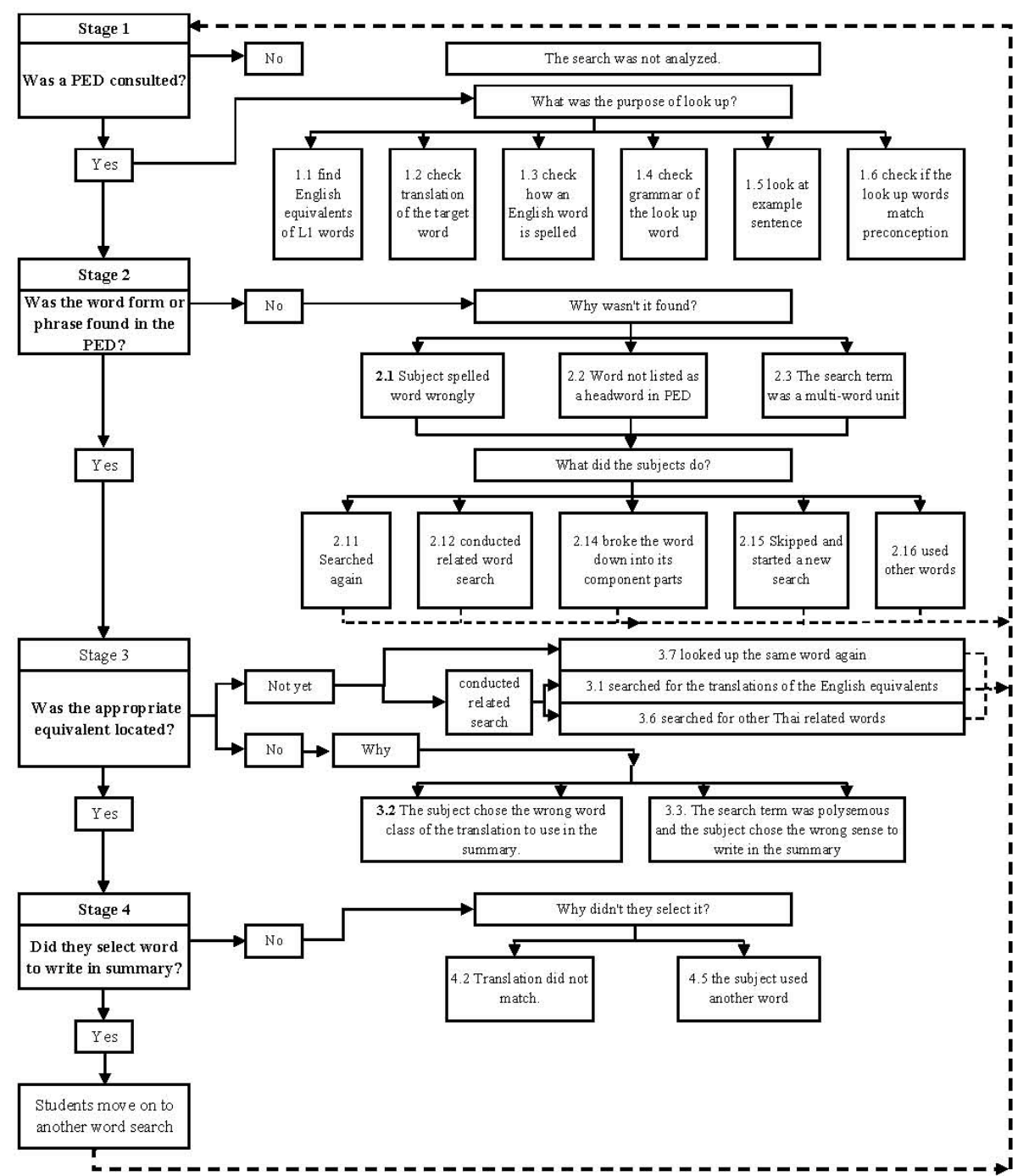

Note The solid line indicates progression throught the stages while the dotted line indicates mov ement backward to the previous stages

Figure 1: Stages in using PEDs for production

Table 3 summarizes the lookup behaviour of each participant, with a special focus on Stage 1, i.e. overall lookups and their purposes. 
Table 3: A summary of lookup behaviour and purposes of dictionary lookups

\begin{tabular}{|c|c|c|c|c|c|c|c|c|c|}
\hline & \multicolumn{5}{|c|}{ TalkingDict Users } & \multicolumn{3}{|c|}{$\begin{array}{l}\text { CyberDict } \\
\text { Users }\end{array}$} & \multirow{2}{*}{ Total } \\
\hline & A & B & $\mathrm{C}$ & D & E & F & G & $\mathbf{H}$ & \\
\hline Total minutes taken & 60 & 40 & 43 & 40 & 45 & 36 & 35 & 40 & \\
\hline Total number of lookups $\left({ }^{*} 1+{ }^{*} 2+{ }^{*} 3\right)$ & 85 & 47 & 12 & 18 & 34 & 14 & 12 & 28 & $\begin{array}{c}250 \\
(100 \%) \\
\end{array}$ \\
\hline \multicolumn{10}{|l|}{ Purpose of lookup } \\
\hline To find English equivalents & 85 & 29 & 10 & 16 & 25 & 14 & 10 & 10 & $\begin{array}{c}199 \\
(79.6 \%)\end{array}$ \\
\hline $\begin{array}{c}\text { To check translations of English } \\
\text { equivalents }\end{array}$ & - & 17 & 2 & - & 6 & - & 1 & 10 & $\begin{array}{c}36 \\
(14.4 \%) \\
\end{array}$ \\
\hline To check spelling & - & - & - & 2 & 1 & - & 1 & 2 & $\begin{array}{c}6 \\
(2.4 \%)\end{array}$ \\
\hline $\begin{array}{l}\text { To check if the word matched their } \\
\text { preconception }\end{array}$ & - & 1 & - & - & 2 & - & - & 3 & $\begin{array}{c}6 \\
(2.4 \%)\end{array}$ \\
\hline To check grammar & - & - & - & - & - & - & - & 1 & $\begin{array}{c}1 \\
(0.4 \%)\end{array}$ \\
\hline To look at example sentences & - & - & - & - & - & - & - & 2 & $\begin{array}{c}2 \\
(0.8 \%)\end{array}$ \\
\hline Number of words looked up *1 & 70 & 24 & 9 & 17 & 22 & 12 & 10 & 16 & 180 \\
\hline $\begin{array}{c}\text { Number of related lookups } * 2 \text { (out of } \\
\text { actual words) }\end{array}$ & $\begin{array}{l}7 \\
(6)\end{array}$ & $\begin{array}{l}22 \\
(12)\end{array}$ & $\begin{array}{l}3 \\
(2)\end{array}$ & $\begin{array}{c}1 \\
(1)\end{array}$ & $\begin{array}{l}11 \\
(7)\end{array}$ & $\begin{array}{c}2 \\
(1)\end{array}$ & $\begin{array}{c}1 \\
(1)\end{array}$ & $\begin{array}{l}11 \\
(6)\end{array}$ & $\begin{array}{c}58 \\
(36)\end{array}$ \\
\hline $\begin{array}{l}\text { Number of repeated lookups } * 3 \text { (out of } \\
\text { actual words) }\end{array}$ & $\begin{array}{l}8 \\
(6)\end{array}$ & $\begin{array}{c}1 \\
(1)\end{array}$ & 0 & 0 & $\begin{array}{c}1 \\
(1)\end{array}$ & 0 & $\begin{array}{c}1 \\
(1)\end{array}$ & $\begin{array}{c}1 \\
(1)\end{array}$ & $\begin{array}{c}12 \\
(10)\end{array}$ \\
\hline
\end{tabular}

The average time spent doing the summary task was 42 minutes. Other participants, however, spent \pm 7 minutes of the average time in doing the summary task. Considering Table 3 alone, it may be sensible to conclude that participant A made use of the least number of features of his dictionary. He used the PED only to find the English equivalents of the Thai words (using only the default Thai-English dictionary). Participant $\mathrm{H}$ made the most use of his dictionary, using both the Thai-English dictionary (for English equivalents) and the English-Thai dictionary (for English translations), exploring the lexicographical features of the PED (i.e. grammar, example sentences), and having various reasons for lookups (e.g. checking spelling).

The total number of lookups ranged from 12 (C and G) to 85 (A). Participant A looked up 70 different words. The remaining participants looked up from as few as nine (participant $C$ ) to as many as 24 different words (participant $\mathrm{B}$ ). It should be noted, however, that although $\mathrm{B}, \mathrm{E}$, and $\mathrm{H}$ conducted 47 , 
34 , and 28 searches respectively, they only looked up 24, 22, and 16 different words. These three participants conducted many related word searches.

For related lookups, it should be noted that all of A's related lookups were different from those of the three participants (B, E, and H) above. All of A's related lookups were to search for other related Thai words (related search type I). On the other hand, almost all related searches made by B, E, and $\mathrm{H}$ were to search for the translations of English equivalents (related search type II). These three participants were more likely than A to be concerned about the appropriate use of the equivalents.

Table 4 summarises the lookup behaviour of each participant, with a special focus on stage 2, i.e. successful and unsuccessful lookups. The overall success rate was $89.6 \%$ (224 out of 250 lookups) and the overall failure rate was $10.4 \%$ (26 out of 250 lookups).

There were 26 unsuccessful lookups, and the most frequent reason for failure was that the search words were not included in the PEDs (12 lookups), the second most frequent reason was that the search term was a multi-word unit (10 lookups), and the last reason was that search words were incorrectly spelled (4 lookups).

Some of the words and expressions that were not listed in the PEDs were การดำรงชีวิต [kan damrongchiwit] (the act of maintaining one's life) and การดำรง [kan damrong] (the act of maintaining, keeping). In Thai, derived forms are created by adding a prefix to the stem of a word. Therefore, the search would have been successful if a participant had looked up the root form (the verbal form) ดำรงชีวิต [damrongchiwit] or ดำรง [damrong] in his PED.

A multi-word unit could be broken down into single words. For example, A was unable to find เขตหนาว [khet nao] (cold area), which can be separated into เขต [khet] (area, location) and หนาว [nao] (cold), both of which, of course, are listed.

Table 4: Successful and unsuccessful lookups

\begin{tabular}{|l|c|c|c|c|c|c|c|c|c|c|}
\hline \multirow{2}{*}{ STAGE 2 } & \multicolumn{5}{|c|}{ TalkingDict } & \multicolumn{3}{c|}{$\begin{array}{c}\text { CyberDict } \\
\text { Users }\end{array}$} & \multirow{2}{*}{ Total } \\
\cline { 2 - 12 } & A & B & C & D & E & F & G & H & \\
\hline Did participants find words in their PEDs? & & & & & & & & & \\
\hline - Yes & 72 & 45 & 11 & 16 & 31 & 11 & 11 & 27 & 224 \\
\hline - No & 13 & 2 & 1 & 2 & 3 & 3 & 1 & 1 & 26 \\
\hline Why didn't they find the words? & & & & & & & & & \\
\hline - Participant spelled word incorrectly & 1 & 1 & - & - & 1 & - & 1 & - & 4 \\
\hline - Word not listed as a headword in PED & 6 & - & 1 & 1 & 1 & 3 & - & - & 12 \\
\hline - Search term was a multi-word unit & 6 & 1 & - & 1 & 1 & - & - & 1 & 10 \\
\hline
\end{tabular}




\begin{tabular}{|l|c|c|c|c|c|c|c|c|c|}
\hline What did they do? & & & & & & & & & \\
\hline - Searched again & - & - & - & - & 1 & - & - & - & 1 \\
\hline - Conducted related word search & 1 & - & - & 1 & 1 & 2 & - & - & 5 \\
\hline - Broke the word down & 5 & 1 & - & - & - & - & - & 1 & 7 \\
\hline - Skipped and started a new search & 7 & 1 & - & 1 & - & - & - & - & 9 \\
\hline - Used other words & - & - & 1 & - & 1 & 1 & 1 & - & 4 \\
\hline
\end{tabular}

Table 5 summarises the lookup behaviour of each subject, with a special focus on Stage 3, appropriateness of equivalents. As indicated above, $89.6 \%$ of lookups were successful. However, this does not necessarily imply that the participants were able to locate appropriate English equivalents of search words to write in their summaries, nor does it imply that the PEDs contained sufficient headwords, or that the participants possessed good dictionary skills. This author considers locating (and using) appropriate English equivalents to be the most crucial part of the dictionary consultation process, since it directly contributes to the success of the writing of the summary. Although there are several factors contributing to this success, for example, grammatical knowledge and stylistics, these are not relevant to dictionary use. Stage 3 investigates whether or not the participants could locate the most appropriate English equivalents of the Thai words (see Table 5).

As mentioned earlier, not every lookup can be straightforwardly classified as appropriate or inappropriate. Some lookups may take longer to classify than others. It can be seen that out of 224 successful lookups from stage 2, 159 $(70.9 \%)$ could be classified as appropriate. Forty-three lookups were classified as 'not yet' because the participants did not simply locate the equivalents but conducted further searches before making a decision. Twenty-two lookups $(9.8 \%)$ resulted in inappropriate equivalents being found.

Table 5: Appropriateness of equivalents

\begin{tabular}{|c|c|c|c|c|c|c|c|c|c|}
\hline \multirow{2}{*}{$\begin{array}{l}\text { STAGE } 3 \\
\text { Did the participants locate the } \\
\text { appropriate equivalents? }\end{array}$} & \multicolumn{5}{|c|}{$\begin{array}{c}\text { TalkingDict } \\
\text { users }\end{array}$} & \multicolumn{3}{|c|}{$\begin{array}{c}\text { CyberDict } \\
\text { users }\end{array}$} & \multirow[t]{2}{*}{ Total } \\
\hline & A & B & C & D & E & $\mathbf{F}$ & G & $\mathbf{H}$ & \\
\hline -Yes & 64 & 24 & 5 & 14 & 20 & 7 & 7 & 18 & 159 \\
\hline - Not yet & - & 20 & 3 & - & 9 & - & 2 & 9 & 43 \\
\hline- No & 8 & 1 & 3 & 2 & 2 & 4 & 2 & - & 22 \\
\hline \multicolumn{10}{|l|}{ If not yet, what did they do? } \\
\hline $\begin{array}{l}\text { - searched for translations of the } \\
\text { English equivalents }\end{array}$ & - & 14 & 2 & - & 6 & - & - & 8 & 30 \\
\hline
\end{tabular}




\begin{tabular}{|l|c|c|c|c|c|c|c|c|c|}
\hline - searched for other related Thai words & - & 5 & 1 & - & 1 & - & 1 & - & 8 \\
\hline - looked up the same word again & - & - & - & - & 1 & - & 1 & 1 & 3 \\
\hline If no, why? & & & & & & & & & \\
\hline - wrong part of speech & 4 & - & - & - & 1 & - & - & - & 5 \\
\hline - word sense & 4 & 1 & 3 & 2 & 1 & 4 & 2 & - & 17 \\
\hline
\end{tabular}

The last two categories ('not yet' and 'no') merit further discussion in this section. Participants A, D, and F did not interrupt their search to consider other alternatives before deciding which equivalents they would use in their summaries. In contrast, $\mathrm{B}, \mathrm{C}, \mathrm{E}$, and $\mathrm{H}$ did not locate the equivalent in the first instance, but used one of three alternative strategies first. Out of 43 lookups, 30 involved searching for translations of the English equivalents, followed by searching for other related Thai words and lastly, looking up the same word in Thai again. This may be the most important of the alternative strategies because it seems to indicate that the participants were concerned about the appropriateness of the English translation. They wanted the equivalent to convey the closest meaning to the Thai headword. An interview with participant $B$ revealed how he used his PED.

Researcher: Can you briefly explain how you used your PED?

B:

I used the PED when I didn't know the English equivalent. And when there were many equivalents provided, I would look up all of their meanings in the English-Thai dictionary. I want to check each equivalent because sometimes it could mean something different. For example, the Thai word ซึม [Suem] can be used to mean ซึมเศ้วาไปเลย [SuemSaoPaiLoei] (feeling very sad) or it can be used to mean นำซึ่มลงดิน [NamsuemLongDin] (water oozes on the ground). They have completely differently meanings so I have to look up all their equivalents in the PED. If I used it incorrectly, the meaning will be different too.

(My translation of B's Interview)

\subsection{The Water II Experiment}

This section will report on the opinions of the remaining five participants when using an English-English dictionary to review their summaries. The participants went through the same procedures as in the previous task but they were then invited to use the English-English dictionary (the OALD 6th) included in their PEDs to revise what they had written. The findings are shown in Table 6.

Table 6 shows that the purpose of lookups for all participants (except A2) was to check if the meanings of English equivalents were the meanings they 
intended, and also to check the translations of the English words.

Table 6: Lookup behaviour using an English-English dictionary

\begin{tabular}{|c|c|c|c|c|c|}
\hline \multirow{2}{*}{ Categories } & \multicolumn{5}{|c|}{ Participant } \\
\hline & A2 & B2 & $\mathrm{C} 2$ & D2 & E2 \\
\hline \multicolumn{6}{|l|}{ 1) Purpose of lookups } \\
\hline $\begin{array}{l}\text { Check if the meaning of English equivalent } \\
\text { is the one intended }\end{array}$ & & $\checkmark$ & $\checkmark$ & $\checkmark$ & $\checkmark$ \\
\hline Check translations of the English words & & $\checkmark$ & $\checkmark$ & $\checkmark$ & $\checkmark$ \\
\hline $\begin{array}{l}\text { Look for grammatical and usage informa- } \\
\text { tion }\end{array}$ & $\checkmark$ & & & & \\
\hline $\begin{array}{l}\text { Compare English words in order to choose } \\
\text { the most appropriate one }\end{array}$ & $\checkmark$ & & $\checkmark$ & & $\checkmark$ \\
\hline 2) Exploitation of polysemous entries & Fully & Partly & Fully & No & Partly \\
\hline 3) Use of help options provided by PEDs & $\checkmark$ & & $\checkmark$ & & \\
\hline 4) Changes made to the summary & $\checkmark$ & $\checkmark$ & $\checkmark$ & & $\checkmark$ \\
\hline $\begin{array}{l}\text { 5) Displayed knowledge of PED (e.g. abbre- } \\
\text { viations, grammar) }\end{array}$ & Fully & None & Partly & Partly & Partly \\
\hline Highlighting a word & $\checkmark$ & & $\checkmark$ & $\checkmark$ & $\checkmark$ \\
\hline Highlighting two words or more & $\checkmark$ & & $\checkmark$ & & \\
\hline Using the backspace function & $\checkmark$ & & $\checkmark$ & & \\
\hline Comprehension of the abbreviation e.g. & $\checkmark$ & & & $\checkmark$ & $\checkmark$ \\
\hline Comprehension of the abbreviation sth & $\checkmark$ & & & & \\
\hline $\begin{array}{l}\text { Distinguishing between countable and } \\
\text { uncountable nouns }\end{array}$ & $\checkmark$ & & $\checkmark$ & $\checkmark$ & $\checkmark$ \\
\hline
\end{tabular}

In terms of polysemous entries, only A2 and C2 exploited all the entry information. It was observed that they always scrolled down to see what other information was available. They also often looked for example sentences. For example, C2 searched for the word natural, which yielded eight senses (signposts) i.e. IN NATURE, EXPECTED, BEHAVIOUR, ABILITY, RELAXED, PARENT/CHILDREN, BASED ON HUMAN REASON and IN MUSIC. The think-aloud protocol confirms that $\mathrm{C} 2$ explored all these senses before making the decision whether to make changes to the summary. 


\begin{tabular}{|c|c|}
\hline natural & \\
\hline adj., noun & \\
\hline Adj. & PED screen \\
\hline IN NATURE & \\
\hline 1. [only before noun] existing in nature; not & \\
\hline 1 e.g. & \\
\hline Made or caused by human beings: e.g. & \\
\hline -- compare SUPERNATURAL & \\
\hline EXPECTED & \\
\hline 2. normal; as you would expect: e.g. $\quad$ (line 10) & \\
\hline -- compare UNNATURAL & \\
\hline$\underline{B E H A V I O U R}$ & \\
\hline 3. used to describe behaviour that is part of & \\
\hline the character that a person or an animal & \\
\hline Was born with: e.g. $\quad$ (line 15) & \\
\hline ABILITY & \\
\hline 4. [only before noun] having an ability that & \\
\hline you were born with: e.g. & \\
\hline$\underline{\text { RELAXED }}$ & \\
\hline 5. relaxed and not pretending to be sb/sth (line 20) & \\
\hline Different: e.g. & \\
\hline PARENTS/CHILDREN & \\
\hline 6. [only before noun] (of parents or their & \\
\hline Children) related by blood: e.g. & \\
\hline 7. [only before noun] (old use or formal) (line 25) & \\
\hline (of a son or daughter) born to parents who & \\
\hline are not married & \\
\hline$((S Y N))$ ILLEGITIMATE e.g. & \\
\hline BASED ON HUMAN REASON & \\
\hline
\end{tabular}




\begin{tabular}{|l|}
\hline 8. [only before noun] based on human $\quad$ (line 30) \\
\hline reason alone: e.g. \\
\hline IN MUSIC \\
\hline 9. used after the name of a note to show \\
\hline That the note is neither SHARP nor FLAT. \\
\hline The written symbol is : e.g. \\
\hline Noun \\
\hline PERSON \\
\hline
\end{tabular}

Figure 2: The main entry for the search for NATURAL

Compare the think-aloud protocol that illustrates C2's exploration of all senses of the word NATURAL:

คำต่อมา (the next headword) n-a-t-u-r-a-l r-e-c-o ... ฮะ! (aha) natural resource ... ไม่มีจริงๆ ด้วย เอาเป็น (did not exist in the PED, so) natural พอ. (should be enough).. natural... natural ที่ เป็น (searching for) natural เป็น (that functioned as a) noun... compare you would you would expect... describe behaviour that is part of the character... natural อะไรเนี ย นิสัยที่ มีตั งแต่เกิดหร(๓) hat is this? Behaviour since you were born?)... นิสัยที่ มีตั งแต่เกิด ไม่ใช่(I don't think it is this sense).. human an ability... skill ที มีตั งแต่เกิด that you born with) ability ที่ มีตั งแต่เกิด (that you were born with)... นี ไง(oh..here it is) relaxed and not pretending to be... only before noun...

The participant paused for a while so I interrupted and asked, what are you thinking?

(this sense is used before) ใช้ได้เฉพาะ noun เป็นได้เฉพาะ (it can be) noun อือ... of of parents or their children relate by blood อ๋อ! (oh.. I see!) old use or formal born to parents who are not married... born parents who are not married... only before noun... _ ....ตัวนี ไม่ใช่ (not this sense) normal music มาเกี ยวอะไร (not relevant) a person who is ไม่ใช่... (no) เออ $(a h h)$ based on human reason alone _ ไม่ใช... ตัวนี ไม่ใช่(no.. this not this sense either)

On the other hand, B2 and E2 sometimes looked at only a few more lines beyond the initial PED screen. D2 was the only participant who only viewed the information that was available on the screen. It was observed that out of five lookups, none of the entries were explored beyond the first few lines. 
Only A2 and C2 made use of the help options provided by their PEDs while using the English-English dictionary to review their summaries. All participants except D2 made minor changes to their summaries. Some added a new sentence; some deleted some words; and some used a new word to replace one used previously. They all agreed that the OALD was useful, but they still preferred to use the default English-Thai dictionary in the PEDs.

A2 was by far the most able to demonstrate knowledge and familiarity with the CyberDict PED form and OALD content. She exploited all subentries, used help options provided by the PED, and knew the abbreviations used in the dictionary. She knew how to highlight a word or a group of words in order to conduct cross searches and how to use the backspace button (deleting the preceding character). Inadequate knowledge of the PED features and specific knowledge of the particular conventions of the dictionary (in this case OALD) would lead users to make mistakes. An interview with B2 confirmed that she is the least efficient PED user. During this interview, it was established that she was unable to decode abbreviations, ...,

Researcher: Do you know abbreviations used in this dictionary (OALD)?

B2: Can you give me some examples?

Researcher: How about this one—sth? I pointed to the signpost $\sim$ (about/over sth)

B2: $\quad$ Oh sth. I don't know.

Researcher: You don't know?

B2: $\quad$ No.

Researcher: That's ok. Now look at the word PARTICULAR in the dictionary. Do you understand what this means in brackets? [only before noun]

B2: $\quad$ No.

Researcher: How about AmE?

B2: $\quad$ No, I don't.

Researcher: Do you know how to highlight a group of words, for example highlighting the word 'look' and 'up' at the same time?

B2: $\quad$ I don't know.

Researcher: Ok. When you spelt incorrectly, for example the word 'solution', it should be S-O-L-U but you accidentally typed S-O-L-E, do you know how to delete the 'E'?

B2: $\quad$ I really don't know. I have been trying to find this button since I first bought it but I can't find it. So I just type the words again. 
Researcher: Have you read the manual?

B2: $\quad$ Yes. But I think I couldn't find it. And the manual was also in English.

It is clear from the interview that participant B2 lacked 1) skills in using a dictionary in electronic format and 2) knowledge of conventions used in the OALD. She was not aware that a different part of speech would affect the meaning. She did not know abbreviations such as sth. And finally, she did not know how to find example sentences.

\section{Summary and Conclusions}

The findings of the Water experiments revealed that the manner in which the participants tackled the Thai reading passage had an effect on how they used their Thai-English dictionary in their PEDs, as well as on how they composed their summaries. The participants encountered problems at every step of the PED consultations and employed various strategies to tackle these problems. The findings revealed that some participants lacked adequate skills in PED use. It was found that the use of the English-English dictionary (OALD 6) in the PEDs helped some participants in the production task. Some participants lacked knowledge of PED features and also lacked knowledge of PED dictionary conventions.

This study has confirmed previous assumptions in many respects. The methodology utilised in this study enabled the author to discover exactly how many lines the participants looked up in their PEDs, and it was found that they tended to read only the information available on the PED screen. Few participants would scroll down to see more information. The same tendency to consider only the beginning of entries and ignore any other information has been observed by Wingate (2004) and Winkler (2001) with reference to other kinds of dictionaries. Investigating learners' use of print dictionaries, Wingate (2004) found her participants' lookup behaviour to be superficial and partial. Winkler (2001) reported that when using a dictionary on CD-ROM, her participants had difficulty scanning long entries to find particular details. Nevertheless, although the problem of failing to read beyond the first lines of a long entry seems to occur regardless of dictionary type, PED use is particularly problematic because the PED screen is so small that it severely limits the amount of information that is available at a glance.

This study has confirmed Midlane's findings concerning teachers' assumptions about the type of PED dictionary their students used (2005). In the Water I experiment, all 13 participants only used bilingual dictionaries to deal with the task, but in the Water II experiment the author had to invite five participants to review their summaries using a monolingual learner's dictionary. Although the participants acknowledged that using the English- 
English dictionary had helped them write better summaries, they still stated that they would prefer to consult the bilingual dictionaries in their PEDs before turning to the English-English dictionary component. These findings illustrate Laufer and Kimmel's (1997) distinction between "dictionary usefulness" and "dictionary usability". Similar findings that learners considered their monolingual dictionaries to be very useful for language learning, but preferred to use bilingual dictionaries, are also reported by Taylor and Chan (1994) and Nesi (2003).

Although this study did not focus on look-up speed, it might be sensible to say that the speed with which a PED makes a lookup possible encourages participants to look up many words. This confirms the claims made in PED studies (e.g. Koyama and Takeuchi 2003, Weschler and Pitts 2000) that speed encourages more lookups. Stirling (2005) even claims that speed may encourage overuse. This could be the case for some participants in my study, especially Participant A, who conducted 85 lookups for 70 words in the Water I experiment (the average number of lookups per participant was 31). Participant A looked up 4 words twice and 2 words three times. This shows that Participant A relied heavily on his PED; in his case, the claim that PED encourages overuse seems to be true.

Some other wider issues related to successful and unsuccessful lookups concern the language proficiency and metacognitive knowledge of the participant. It is clear that the participants had different degrees of language ability although all of them were from the same year of study and the same foundation English course. The criteria in selecting the participants were possession of particular PED models and willingness to participate. The participants' language proficiency and metacognitive knowledge were not tested prior to the experiment, although this would naturally have had some effect on their PED skills and strategies.

Previous research (Oxford 2001, Liou 2000) shows that proficiency correlates with cognitive and metacognitive strategies. Participant A was the least proficient PED user, judging by his incoherent written summary He relied heavily on his PED and the way he approached the two reading tasks did not seem to involve any metacognitive knowledge of strategies. In contrast, B and $\mathrm{H}$ seem to have higher language proficiency, judging by their written products. Not only did they make use of their PEDs strategically, but they also involved a wide range of metacognitive strategies in dealing with the summary tasks. These findings correspond to those of previous studies. Liou (2000) found that an advanced student group spent less time, looked up fewer words and better understood the reading task than a lower language ability group. Also, the advanced student group did not only rely on dictionaries but also on other strategies, for example, guessing, making inferences, and using background knowledge. The findings are also in accordance with Fan's findings (2000) that high proficiency learners make fuller use of their dictionaries. Participants in this study who demonstrated greater knowledge 
of English also reported using contextual meaning and information about appropriateness more often and regarded them as more useful than lower proficiency learners. Taking these findings into account, it may be appropriate to say that PED skills are to some extent affected by language proficiency and generic language learning abilities.

\section{References}

Al-Ajmi, H. 2002. Which Microstructural Features of Bilingual Dictionaries Affect Users' Look-up Performance? International Journal of Lexicography 15(2): 119-131.

Atkins, B.T.S. and K. Varantola. 1998. Monitoring Dictionary Use. Atkins, B.T.S. (Ed.). 1998. Using Dictionaries: Studies of Dictionary Use by Language Learners and Translators. Lexicographica. Series Maior 88: 83-122. Tübingen: Max Niemeyer Verlag.

Boonmoh, A. 2003. Problems with Using Electronic Dictionaries to Translate Thai Written Essays into English. Unpublished M.A. Thesis, King Mongkut's University of Technology Thonburi, Bangkok.

Boonmoh, A. 2009. The Use of Pocket Electronic Dictionaries by Thai Learners of English. Unpublished Ph.D. Thesis, University of Warwick, UK.

Boonmoh, A. and H. Nesi. 2008. A Survey of Dictionary Use by Thai University Staff and Students, with Special Reference to Pocket Electronic Dictionaries. Horizontes de Lingüística Aplicada 6(2): 79-90.

Cohen, A.D. 1998. Strategies in Learning and Using a Second Language. New York: Addison Wesley Longman.

Deng, Y.P. 2005. A Survey of College Students' Skills and Strategies of Dictionary Use in English Learning. CELEA Journal 28(4): 73-77.

Diab, T. 1990. Pedagogical Lexicography: A Case Study of Arab Nurses as Dictionary Users. Lexicographica. Series Maior 31. Tübingen: Max Niemeyer Verlag.

Diab, T.A. and J. Hamdan. 1999. Interacting with Words and Dictionaries: The Case of Jordanian EFL Learners. International Journal of Lexicography 12(4): 281-305.

Ericsson, K.A. and H.A. Simon. 1980. Verbal Reports as Data. Psychological Review 87(3): 215-251.

Fan, M.Y. 2000. The Dictionary Look-up Behaviour of Hong Kong Students: A Large-scale Survey. Education Journal 28(1): 123-138.

Frankenberg-Garcia, A. 2005. A Peek into What Today's Language Learners as Researchers Actually Do. International Journal of Lexicography 18(3): 335-355.

Jopling, F. 2003. Towards a New Methodology for Research on Electronic and Paper-based Dictionary Use: A Pilot Study of Look-up Patterns on Screen and in Print. Unpublished M.A. Thesis. Coventry: University of Warwick.

Koren, S. 1997. Quality Versus Convenience: Comparison of Modern Dictionaries from the Researcher's, Teacher's and Learner's Points of View [online]. Teaching English as a Second or Foreign Language 2(3). Available: http://www-writing.berkeley.edu/TESL-EJ/ej07/a2.html [27 June 2006]. 
Koyama, T. and O. Takeuchi. 2003. Printed Dictionaries vs. Electronic Dictionaries: A pilot Study on how Japanese EFL Learners differ in Using Dictionaries. Language Education and Technology 40: 61-79.

Laufer, B. and M. Kimmel. 1997. Bilingualised Dictionaries: How Learners Really Use Them. System 25(3): 361-369.

Liou, Hsien-Chin. 2000. The Electronic Bilingual Dictionary as a Reading Aid to EFL Learners: Research Findings and Implications. Computer Assisted Language Learning 13(4-5): 467-476.

Matsumoto, K. 1993. Verbal-report Data and Introspective Methods in Second Language Research: State of the Art. RELC Journal 24(1): 32-60.

Midlane, V. 2005. Students' Use of Portable Electronic Dictionaries in the EFL/ESL Classroom: A Survey of Teacher Attitudes. M.Ed. Dissertation. Manchester: University of Manchester, Faculty of Education.

Mongphet, S. 2007. Appropriateness of Vocabulary Chosen from Thai-English Electronic Dictionaries in Writing. Unpublished M.A. Thesis, King Mongkut's University of Technology Thonburi, Bangkok.

Nesi, H. 2003. The Virtual Vocabulary Notebook: The Electronic Dictionary as Learning Tool. Paper presented at the BALEAP Conference, Developing Academic Literacy, University of Southampton 10-12 April 2003.

Nesi, H. and A. Boonmoh. 2009. A Close Look at the Use of Pocket Electronic Dictionaries for Receptive and Productive Purposes. Fitzpatrick, T. and A. Barfield (Eds.). 2009. Lexical Processing in Second Language Learners: 67-81. Clevedon, UK: Multilingual Matters.

Nesi, H. and R. Haill. 2002. A Study of Dictionary Use by International Students at a British University. International Journal of Lexicography 15(4): 277-305.

Oxford, R. 2001. Language Learning Styles and Strategies. Celce-Murcia, M. (Ed.). 2001. Teaching English as a Second or Foreign Language. Third edition. Boston, MA: Heinle \& Heinle.

Paisart, W. 2004. An Investigation of Dictionary Use to Facilitate Reading Comprehension. Unpublished M.A. Thesis, KMUTT.

Sobkowiak, W. 2002. The Challenge of Electronic Learner's Dictionaries [online]. Teaching English with Technology: A Journal for Teachers of English 2(1). Available: http://www.iatefl.org.pl/ call/j_article7.htm\#sob [2006, May 27].

Stirling, J. 2005. The Portable Electronic Dictionary — Faithful Friend or Faceless Foe? Modern English Teacher 14(3): 64-72.

Tang, G. 1997. Pocket Electronic Dictionaries for Second Language Learning: Help or Hindrance? TESL Canada Journal 15(1): 39-57.

Taylor, A. and A. Chan. 1994. Pocket Electronic Dictionaries and Their Use. Martin, W., W. Meijs, M. Moerland, E. ten Pas, P. van Sterkenburg and P. Vossen (Eds.). 1994. Euralex 1994 Proceedings, Papers Submitted to the 6th EURALEX International Congress on Lexicography in Amsterdam, The Netherlands: 598-605. Amsterdam: VU University Amsterdam.

Tono, Y. 2001. Research on Dictionary Use in the Context of Foreign Language Learning: Focus on Reading Comprehension. Lexicographica. Series Maior 106. Tübingen: Max Niemeyer Verlag. 
Weschler, R. and C. Pitts. 2000. An Experiment Using Electronic Dictionaries with EFL Students [online]. The Internet TESL Journal 6(8). Available: http://iteslj.org/Articles/Weschler-ElectroDict. html [3 September 2007].

Wingate, U. 2004. Dictionary Use - The Need to Teach Strategies. Language Learning Journal 29(1): 5-11.

Winkler, B. 2001. Students Working with an English Learners' Dictionary on CD-ROM. Papers from the ITMELT 2001 Conference. Available: http://elc.polyu.edu.hk/conference/papers2001/winkler. htm [6 January 2007]. 


\title{
Appendix A: Thai Reading Passage: Water
}

\author{
นำ (อังกฤษ: water) เป็นของเหลวชนิดหนึ งซึ งถ้าบริสุทศิะไม่มีรส ไม่มีกลิ น และไม่มีสี \\ นำเป็นของเหลวที มีอยู่มากที สุดบนผิวโลก \\ และเป็นปัจจัยสำคัญต่อการดำรงชี่วิตของสิ งมีชีวิตทุกชนิดที่ มนุษย์รูจจัก เราสามารถพบนำ ได้ในหลายๆ สถานที \\ อาทิ ทะเล ทะเลสาบ แม่นำ ห้อย หนอง คลอง บึง และในหลายๆ รูปแบบ เช่น นำแข็ง หิมะฝน ลูกเห็บ เมฆ \\ และไอนำ \\ นำมีสมบัติเป็นตัวทำละลายที่ ดีมาก เราจึงไม่ค่อยพบนำบริสุในิธิธรรมชาติ \\ ดังนั นนำสะอาดที่ เหมาะสมต่อการบริโภคของมนุษย์จึงเป็นทรัพยากรที่ มีค่ายิง \\ ในบางประเทศปัญหาการขาดแคลนนำเป็นปัญหาใหญ่ที ส่งผลกระทบต่อสังคม \\ และเศรษฐกิจของประเทศนั นอย่างกว้างขวาง \\ นำมีหลายรูปแบบ เช่น ไอนำและเมฆบนท้องฟ้า คลื นและก้อนนำแข็งในทะเล ธารนำแข็งบนภูเขา \\ นำบาดาลใต้ดินฯลฯ นำเปลี ยนแปลงรูปแบสถานะ และสถานที่ ของมันตลอดเวลา \\ โดยผ่านกระบวนการกลายเป็นไอ ตกลงสู่พื่ นดิน ซึม ชะล้างและไหล \\ ก่อให้เกิดการหมุนเวียนของนำ าบผิวโลกเรียกว่าวัฏจักรของนำ \\ เนื องจากการตกลงมาของนำมีความสำคัญอย่างยิ งต่อการเกษตรและต่อมนุษย์โดยทั วไป \\ มนุษย์จึงเรียกการตกลงมาของนำแบบต่างๆ ด้วยชื อเฉพาะตัฉน ลูกเห็บ หมอก \\ และนำค้างเป็นการตกลงมาของนำที พบได้ทั วโลก แต่หิมะและนำค้างแข็งมีเฉพาะในประเทศเขตหนาว \\ รุ้งเป็นปรากฏการณ์ที่ เกิดขึ นเมื อละอองนำ ในอากาศต้องแสงอาทิตย์ในมุมที่ เหมาะสม \\ http:/ / th.wikipedia.org/wiki/\%E0\%B8\%99\%E0\%B9\%89\%E0\%B8\%B3 \\ Accessed on February 5, 2006
}

\section{My summary}

Water is a liquid. Pure water is tasteless, odorless, and has no colour. Water is very important for living things. Water appears mostly in places such as seas, lakes, and ponds. Moreover, it can also appear in the form of snow, rain water or clouds. Water changes its form, state, and place all the time through complex processes. This results in water circulation on and above the surface of the earth. This phenomenon is called the 'Circle of Water'. Although we know that water is very important for living things, we rarely see pure water in nature. As a result, clean water which is suitable for humans is vital. In some countries, there are a lot of serious water problems and they can affect the society and economy of those countries. 


\section{Appendix B: Guideline Interview Questions}

\section{Reading a text in Thai and writing a summary in English (production)}

- Can you explain how you normally use your pocket electronic dictionary for writing?

- For the first task, i.e. writing a summary in English, what did you do before you wrote?

- What were your difficulties in writing this paragraph, sentence, or word?

- I noticed you did this/that. Why?

- Did you encounter problems when you used your own PED dictionary for this task? If so, what were the problem(s)?

- How do you solve the problem(s)?

- Are there any differences when you used your electronic dictionary for this task and in your spare time?

\section{Reading a text in Thai and writing a summary in English (production)}

- How did you feel when you used an English-English dictionary to review this task?

- Is there any difference between using a Thai-English dictionary and an English-English dictionary? If so, what are the differences?

- I noticed you did this/that. Why?

- Did you encounter problems when you used your own PED for this task? Is so, what were the problem(s)?

- How did you solve the problem(s)?

- What changes have you made after consulting this dictionary? Why? 